Relations industrielles

Industrial Relations

\title{
Salaire familial et revenu familial
}

\section{Gérard Dion}

Volume 15, numéro 1, janvier 1960

URI : https://id.erudit.org/iderudit/1022068ar

DOI : https://doi.org/10.7202/1022068ar

Aller au sommaire du numéro

Éditeur(s)

Département des relations industrielles de l’Université Laval

ISSN

0034-379X (imprimé)

1703-8138 (numérique)

Découvrir la revue

Citer cet article

Dion, G. (1960). Salaire familial et revenu familial. Relations industrielles / Industrial Relations, 15(1), 2-30. https://doi.org/10.7202/1022068ar
Résumé de l'article

L'auteur présente ici une étude de morale sociale. Après avoir exposé le fondement sur lequel repose le droit à la sécurité économique pour la famille, il établit le rapport qui existe entre le travail et la rétribution familiale. Il discute le problème complexe du salaire familial en tenant compte des opinions les plus récentes émises sur ce sujet.
Tous droits réservés (C Département des relations industrielles de l’Université Laval, 1960
Ce document est protégé par la loi sur le droit d'auteur. L’utilisation des services d'Érudit (y compris la reproduction) est assujettie à sa politique d'utilisation que vous pouvez consulter en ligne.

https://apropos.erudit.org/fr/usagers/politique-dutilisation/ 


\section{Salaire familial et revenu familial}

\section{Gérard Dion}

L'auteur présente ici une étude de morale sociale. Après avoir exposé le fondement sur lequel repose le droit d la sécurité économique pour la famille, il établit le rapport qui existe entre le travail et la rétribution familiale. Il discute le problème complexe du salaire familial en tenant compte des opinions les plus récentes émises sur ce sujet.

Le sujet que nous abordons dans cette étude n'est pas l'un des plus faciles. Depuis plus de soixante ans, il fait lobjet de discussions tant chez les théologiens que chez les économistes et peut-être surtout entre moralistes et économistes. On ne peut pas y toucher sans mettre en cause tout régime économique dans son ensemble.

Il ne faut pas croire, cependant, que ce problème puisse être résolu en faisant seulement appel à des principes. C'est une illusion dans laquelle tombent certains moralistes dont les connaissances en sciences économiques ne sont pas toujours à la hauteur de leur compétence dans leur discipline propre.

De plus, comme les Souverains Pontifes, depuis Léon XIII, ont souvent abordé cette difficile question, une exégèse trop strictement littérale des textes peut causer des embarras, car la terminologie n'est pas nécessairement toujours adéquate. Il est souvent arrivé à des móralistes de chercher dans les textes pontificaux une réponse à tout, une expression scientifique ou technique et d'oublier que les papes établissent seulement des principes, donnent des orientations, sans indiquer des méthodes économiques.

Dans cet exposé, nous allons procéder de la façon suivante. Nous allons d'abord établir le fondement de la sécurité économique pour la famille et nous allons voir comment le père de famille peut contribuer par son travail à $\mathrm{y}$ pourvoir et dans quelles

DION, GÉrarD, L.Ph., L.Th., M.Sc. Soc., directeur du département des relations industrielles et professeur a la Faculté des sciences sociales de l'Université Laval, Québec. 
limites. Nous serons ainsi amené à discuter du problème complexe de la rétribution familiale des travailleurs.

\section{Le fondement de la sécurité économique pour la famille}

Si l'on veut trouver le fondement ultime sur lequel repose le droit à la sécurité économique pour la famille, il faut considérer la nature des rapports qui existent entre les biens matériels, la personne humaine et la société.

Le Créateur a mis une hiérarchie dans son oeuvre. Les biens inférieurs sont ordonnés aux biens supérieurs. Ils sont destinés à la satisfaction des besoins de l'homme, tout comme la personne humaine, à cause de son caractère d'être raisonnable et libre, a le droit fondamental d'user de ces biens pour sa subsistance et son épanouissement. Et ce droit que possède chaque homme, du fait qu'il possède la nature humaine, personne, aucune institution ne peut le supprimer, car il est antérieur aux autres.

La thèse de la propriété privée est un corollaire de ce droit. La propriété personnelle n'est qu'un moyen, celui qui correspond le plus sans doute, à la nature raisonnable et libre de la personne humaine, mais toujours seulement un moyen pour réaliser cette destination première et essentielle des biens. Cette propriété personnelle n'est admissible qu'en autant qu'elle y réussit le mieux et de la façon la plus humaine. Elle se place dans l'ordre des moyens et non pas dans celui des fins. Ce droit de propriété est un droit naturel, mais un droit naturel secondaire par rapport au droit naturel primaire que possède chaque être humain à se servir des biens matériels pour sa subsistance et son épanouissement. ${ }^{1}$

Mais il ne faut pas oublier que lhomme est naturellement sociable. Deux sociétés lui sont indispensables: la famille et da société civile. Sans société l'homme ne pourrait atteindre son développement physique, intellectuel et moral.

(1) En juin 1941, le pape Pie XII s'exprimait d'une façon magistrale la-dessus UTZ, vol. 1 , no 589 ). 
La famille est la première société à laquelle lhomme appartient. Cest elle qui lui donne la vie, qui lui permet de grandir, de s'éduquer, de se mettre en état de jouer son rôle. La famille est la cellule initiale de la société, l'élément constitutif de la communauté de l'Etat. C'est dans et par la famille que l'enfant peut immédiatement être mis en possession des biens auxquels il a droit comme personne humaine afin de subsister et de se développer. La famille est fonction de ses membres. Et dans l'ordre voulu par le Créateur, ce sont les parents qui, en se partageant les tâches, ont la responsabilité directe de nourrir les enfants, de les éduquer, de les protéger et de leur fournir tout ce qui leur est nécessaire. Comme dans toute société il y a un chef, c'est en premier lieu sur le père de famille que reposent le devoir et la responsabilité de pourvoir aux besoins de ses membres, de veiller à ce que la société familiale atteigne sa fin.

La nature sociable de l'homme ne s'épuise pas dans la famille. A côté d'elle on rencontre un nombre considérable de groupements plus ou moins découlant de la nature qui viennent chacun remplir un rôle. Mais au-dessus de tout, la nature exige la société civile. Ce n'est pas le lieu de développer ici de longues thèses sur la nature et le rôle de la société civile. Pour le besoin de notre exposé, contentons nous de rappeler qu'elle n'est pas formée d'agglomérats d'individus et qu'elle vient, à son tour, permettre à l'homme d'atteindre le mieuxêtre à travers tous les groupements qui se trouvent dans son sein. Elle doit les respecter et ne pas absorber les fonctions qu'ils peuvent remplir. Mais elle possède une responsabilité très particulière par rapport à la famille à cause du caractère naturel et essentiel de celle-ci. Elle doit veiller à ce que la famille puisse être en état d'accomplir son rôle et de réaliser la fin que lui a assignée le Créateur. Elle doit la seconder, l'aider et, en aucune manière, devenir une entrave. Et l'ordre économique et social qu'elle a mission de susciter et d'établir doit permettre à la famille d'avoir da sécurité économique sans laquelle celle-ci ne pourrait se maintenir.

Maintenant que nous avons rappelé les rapports essentiels qui doivent exister entre la personne humaine, les biens matériels, la propriété, la société familiale et la société civile, il faut que soit établi un régime par lequel les individus aient accès à ces biens pour leur subsistance et leur développement.

Il faut donc qu'il y ait une organisation juridique particulière qui tieme compte du droit primaire de chacune de ces pensonnes à sa 
subsistance et à son développement par les biens matériels, et aussi de cette société naturelle et nécessaire qu'est la famille.

Or, pour des raisons de viabilité sociale et économique, il est normal que cette distribution des biens matériels soit liée à l'effort de production ou de service de la personne humaine. Chacun des membres de la société aura sa part de biens matériels pourvu qu'il contribue selon la mesure de ses possibilités à la réalisation du bien commun. L'homme, étant sa propre providence, a le devoir de contribuer par son travail et son activité, à la formation de l'ensemble des biens dans la société. Mais ceux qui, par leur situation indépendante de leur volonté, ne peuvent sustenter à leurs propres besoins, ni participer à cette formation du revenu national, ont droit quand même, à titre de personne humaine, à cette portion de biens matériels jugée nécessaire à leur subsistance et à leur épanouissement parce que ce droit, en dernière analyse, est antérieur et indépendant de cet effort. Et c'est le cas de la mère au foyer et des enfants qui ne sont pas en mesure de travailler.

Si nous voulions, à ce moment, synthétiser et établir un ordre de priorité dans les principes que nous avons énoncés, nous dirions:

1-Toute personne humaine a droit à la vie et à son épanouissement;

2-Les biens matériels sont faits pour l'homme;

3 -L'homme est essentiellement sociable;

1 La famille est la première société naturelle à l'homme;

5 - La famille doit être en état de pourvoir aux besoins de ses membres en mettant à leur disposition les biens matériels qui leur sont nécessaires; la responsabilité première incombe au père de famille;

6-La famille comme telle a droit à un revenu suffisant pour faire face à ces besoins et le travail du père de famille et des autres membres, quand ils le peuvent, est un titre immédiat suffisant pour avoir le droit de partager les ressources de l'économie.

Nous voudrions qu'il soit clairement compris qu'il n'est pas question ici d'étatisme ou de prise en charge des enfants et de la famille par l'Etat ou l'ensemble de la société. Mais, abstraction faite de tout système de distribution des biens matériels, la famille a un droit strict 
d un revenu familial, c'est-d-dire suffisant pour faire face à ses obligations concrètes dans le contexte d'une civilisation donnée. Il faudra donc trouver le meilleur système qui pourra respecter ce droit au revenu familial. Et, ne l'oublions pas, quelque système qui sera utilisé n'est pas lui-même un absolu, il aura raison de moyen et non de fin.

Or, le moyen naturel et normal par lequel la famille pourra se procurer ces biens matériels reste toujours et d'abord le travail professionnel du père de famille et de chacun des membres de la famille quand ils pourront le faire. La société doit donc être organisée de telle façon que le père de famille puisse se procurer du travail et qu'il regoive un revenu suffisant pour subvenir aux besoins de ceux dont il a immédiatement la charge. C'est donc dire qu'en morale, il existe d'une part ce que l'on appelle le droit au travail pour que le père de famille puisse accomplir son obligation de travailler et d'autre part aussi le droit au revenu familial.

\section{Travail et rétribution familiale}

Nous avons établi jusqu'ici que la famille a droit à un revenu familial, que le père de famille a l'obligation de contribuer par son travail à pourvoir aux besoins des siens. Il reste maintenant à étudier s'il y a une possibilité d'assurer le revenu familial par les fruits du travail du père de famille.

Nous n'avons pas la prétention de vider cette question tant discutée, ni d'établir une thèse qui va nécessairement amener l'assentiment de tous. Mais nous voudrions, au moins, montrer certains aspects de ce problème complexe et indiquer quelques éléments de solutions qui tiendront à la fois compte et des données de la morale et des données économiques.

Ouvrons d'abord une parenthèse pour écarter rapidement une question. Dans un système où le pouvoir de l'Etat se substitue au mécanisme des prix, ce problème ne se pose pas. On met en pratique l'adage marxiste «de chacun selon ses forces à chacun selon ses besoins » d'une façon simpliste. Le travailleur travaille directement pour l'Etat. Lorsque chacun a fait le travail qui lui est demandé (ou qui lui est imposé), l'Etat, qui assume toutes les fonctions économiques, se charge aussi d'opérer lui-même la distribution du revenu national et attribue aux citoyens ce qu'il juge leur falloir. On sait, cependant, que 
ce système met en question bien d'autres valeurs essentielles plus importantes qu'une simple distribution de biens matériels. Ce n'est pas le lieu de le refuter ici.

\section{1-DeUX PRINCIPES ì RÉCONCULIER}

La morale catholique enseigne que le régime du salariat n'est pas essentiellement mauvais. Dans la détermination du salaire, il faut tenir compte à la fois des besoins du travailleur, de la situation de l'entreprise et du bien commun.

Les moralistes sont tous d'accord sur deux principes apparamment contradictoires qu'ils cherchent à réconcilier. Les voici:

\section{a) A travail égal, lemployeur doit payer un salaire égal.}

Il n'y a plus personne aujourd'hui pour soutenir qu'une discrimination quelconque portant sur des éléments extrinsèques au travail lui-même puisse être acceptable. L'employeur doit payer au travailleur l'équivalent de la valeur qu'il a reçue du travailleur. A plusieurs reprises, Pie XII est revenu sur ce sujet. Voici ce qu'il disait en 1947:

* L'Eglise a toujours en vue le vrai bien du peuple entier, le vrai bien commun. Dès lors qu'il s'agit de justes revendications sociales, elle est toujours en tête pour les promouvoir. Une plus équitable répartition des richesses a toujours été et reste toujours un des objectifs principaux de la doctrine sociale catholique. Nous pouvons en dire tout autant de \& la parité du salaire, à travail et à rendement égal entre l'homme et la femme, réclamation que l'Eglise a faite sienne depuis longtemps ». ${ }^{2}$

Dans beaucoup de pays, d'ailleurs, la législation en fait une prescription légale. Le gouvernement fédéral, au Canada, et plusieurs provinces, - pas la province de Québec, - ont édicté une pareille loi.

b) Les chefs de famille qui ont des responsabilités plus grandes ont droit à un revenu en rapport avec ces responsabilités parce qu'ils ont le devoir de faire vivre leur famille.

(2) Allocution à l'union internationale des femmes catholiques, 11 sept. 1947 . UTZ no 1402 . Voir aussi 15 août 1945 , id no $3271 ; 21$ oct. 1945, id no 1434 . 

vail.

C'est ce que nous avons établi dans la première partie de ce tra-

Il n'y a pas de discussion possible sur ces deux principes. La question n'est donc pas de savoir si les chefs de famille doivent ou ne doivent pas recevoir ce dont ils ont besoin, mais bien de savoir de qui ils vont le recevoir et en raison de quelle vertu. C'est là que l'on rencontre des vues différentes.

\section{2-LA DOCTRLNE CLASSIQUE CHEZ LES MORALISTES}

\section{a) Exposé}

La doctrine classique impose directement à l'employeur l'obligation de payer à chaque travailleur, qu'il soit marié ou célibataire, un salaire minimum suffisant pour faire vivre une famille dans un confort décent et raisonnable. Ce devoir pour l'employeur est fondé sur la valeur morale du travail du salarié, valeur déterminée par sa fonction: rendre le travailleur, qui est père de famille en acte ou en puissance, capable de remplir son obligation de pourvoir aux besoins de ses dépendants actuels ou futurs.

Comment peut-on à la fois payer à tous, en dehors des variations dues à la quantité et à la qualité du travail, un salaire qui soit suffisant pour satisfaire aux besoins d'une famille? C'est alors que certains moralistes ont été amenés à distinguer entre le salaire familial relatif et le salaire familial absolu et de parler de justice sociale pour le premier alors qu'ils réservaient la justice commutative pour le second.

\&Le salaire familial relatif est celui qui est de fait proportionné aux besoins de chaque famille. Ce salaire varie d'après le nombre, l'âge et la santé des personnes composant la famille. Il s'élève ou sabaisse selon que la famille est, en fait, plus ou moins nombreuse.

« Le salaire familial absolu est celui qui permet à l'employé de satisfaire aux charges d'une famille ordinaire. Il s'agit ici d'un employé adulte et valide, sobre et honnête, capable d'une somme normale de travail et consacrant tout son temps à une même entreprise ${ }^{3}{ }^{3}$

¿3) Grenier, Cours de Philosophie, tome II, Québec 1942, pp. 374-75. 
Le manuel de philosophie qui est utilisé dans les collèges classiques, comme la plupart des ouvrages parus après Divini Redemptoris, soutient:

«Les théologiens se demandent en vertu de quelle justice le salaire familial absolu est dû à l'employé. Les uns affirment que c'est en vertu de la justice légale. D'autres prétendent que c'est en vertu de la justice distributive. - (C'est ce que le même auteur avait déjà soutenu dans une édition précédente.) - Nous disons que le salaire familial absolu est dû à l'employé en vertu de la justice commutative. Nous ne nions pas que la justice légale impose aussi au patron l'obligation de payer le salaire familial. Cette obligation qui relève de la justice légale, lie le patron envers le bien commun ou la société civile»."

Il faut dire cependant qu'il n'y a jamais eu d'unanimité chez les théologiens sur le genre de justice. Mais tous étaient d'accord pour affirmer que le salaire familial était une responsabilité de lemployeur.

Cette thèse du salaire familial, aussi communément soutenue chez les moralistes, malgré les divergences de détails, qu'ignorée des économistes, a servi, et sert encore, d'argument aux syndicats ouvriers dans leurs réclamations de hausse de salaire et est aussi unanimement et universellement écartée, en pratique, par les employeurs.

Dans le camp des moralistes eux-mêmes, on remarque de plus en plus un certain flottement. Ceux qui s'arrêtent à jeter un coup d'oeil du côté des économistes et, évidemment, ceux qui ont à résoudre les cas de conscience des employeurs scrupuleux, atténuent leurs positions. Ainsi, nous lisons dans la dernière édition (1959) d'un ouvrage publié aux Etats-Unis par un moraliste réputé en ces matières:

\&Earlier versions of this text took the viewpoint that papal authority seemed to be strongly in favor of an obligation in commutative justice. It was noted, however, that in practice «moral impossibility 》 often excused the individual employer from paying such a wage and from the obligation of restitution. Hence as a practical matter the duty to pay a living wage ended up as a problem of social justice, even though it began as a claim in strict justice. In view of these practical difficulties, and some uncertainties in regard to papal teaching, it is now held that the obligation to pay a living wage is primarily a matter of social justice. If the economy were so organized, through proper reforms, that

(4) Grenier, id. p. 377. La même thèse est soutenue par Desrosiers, Soyons fustes, tome II, Montréal, 1945, p. 332. 
the economic value of a worker's contribution at least equaled his claim upon an employer for a living wage, then the worker would also have a claim in strict justice for such a wage. The aequalitas justitiae would then exist, since the value of his services amounted to a living wage ${ }^{5}$

Même après avoir parlé du salaire familial dû en justice sociale, Cronin cite Von Nell-Breuning, qui fait allusion à l'ordre économique ne permettant pas un tel salaire, et ajoute:

\& On this reasoning, the employer is bound in strict justice only to pay a going wage, but in social justice he must co-operate with other economic agents to make a living wage possibles.

Enfin, tenant compte des opinions nouvelles que nous exposerons plus loin, il conclut de la façon suivante:

* All these points, however, must be considered as freely deabatable proposals for implementing a moral principle that is beyond debate. The popes have made clear the moral claim of a worker for a family living wage. They have not discussed, except by way of illustration, the detailed means for securing such a wage ${ }^{\circ}{ }^{6}$

Réaction salutaire et nécessaire contre le libéralisme manohestérien, la doctrine classique n'est pas sans mérite et n'a pas manqué de faire du bien. Elle avait l'avantage d'insister sur un aspect, l'aspect humain dont les employeurs ne voulaient pas tenir compte, aveuglés qu'ils étaient par des préoccupations économiques et peu soucieux de faire les efforts nécessaires pour trouver les moyens de hausser le salaire à un niveau humain.

Jusqu'à il y a quelques années, cependant, rares étaient les moralistes qui osaient attaquer de front cette doctrine classique tant elle apparaissait solidement appuyée sur des textes pontificaux, même si ces textes, comme on le voit aujourd'hui, se gardent de dirimer les controverses. Plusieurs restaient dans des formules générales qui pouvaient être interprétées concrètement de diverses manières.

(5) John Cronin, Social Principles and Economic Life, Bruce, 1959, p. 209; Pouvrage précédent auquel il réfère est Catholic Social Principles, Bruce, 1950 , pp. $356-361$.

(6) p. 213 . 


\section{b) Faiblesses}

Les faiblesses de la doctrine classique du salaire familial dû en justice commutative ou sociale par l'employeur sont tellement grandes qu'à notre sens cette doctrine ne résiste plus à la critique et doit être dépassée. C'est ce qu'ont démontré d'une façon irréfutable les évêques d'Australie, Mgr François Charrière, ancien professeur de morale, aujound'hui évêque de Fribourg, Michael P. Fogarty, professeur à l'Université de Cardiff, le grand spécialiste en politique familiale, le R.P. Pedro Calderan Beltrâo, professeur à l'Université grégorienne de Rome, et le R.P. Bernard William Dempsey, s.j. dans son ouvrage The Functional Economy. Voici les grandes lignes de cette critique.

Le premier reproche que l'on peut faire à la doctrine classique du salaire familial, c'est d'identifier salaire et revenu, alors que le salaire constitue seulement une partie du revenu. On raisonne à partir du revenu familial nécessaire et l'on conclut au salaire familial nécessaire.

De plus, si l'on considère la valeur du travail effectué et que l'on $y$ inclut une part plus grande du fait que quelqu'un est chargé de famille, il faut se demander à qui profite cette valeur accrue. Or celle-ci ne profite pas ordinairement à l'employeur, mais à la société toute entière. Par conséquent, en justice, ce n'est pas à l'employeur qu'il appartient de rémunérer cette valeur spéciale, mais bien à la société elle-même. On peut discuter le mode de le faire, mais c'est une autre question.

Le R.P. Bernard William Dempsey, dont l'autorité en matière d'interprétation des encycliques sociales n'est pas discutée, s'exprime de la façon suivante dans son ouvrage publié l'an dernier:

c As far as the man to man, personal relationship involved in the wage contract, there can be no obligation to pay a living wage if the value of workingmen's services is less than this amount. This is clear from what follows immediately - \& if in the present state of society this is not always feasible »; no one is bound to do what is impossible, that is, not feasible.

< The reason why «the wage paid to the workingman must be sufficient for the support of himself and his family » is of quite diffe- 
rent order than the considerations of strict justice »... «A living wage is due to the worker in commutative justice only conditionally, the condition being that the value of his contribution to the enterprise is equal to the value of a living wage. A living wage is due to the worker in social justice unconditionally.

\& It was unfortunate that much attention has been concentrated on the obligation of the employer to pay a wage in commutative justice, and some writings have indicated a desire to make the unqualified statement that a living wage is due in commutative justice. This of course is not very helpful because, in the case of a business that is really in difficulty for any reason, it imposes a burden that may well be quite impossible to fulfil. The right then becomes meaningless. These proponents of a living wage in commutative justice regardless of the worker's capacity or performance are like the socialists spoken of elsewhere in the encyclical who «go too far in vindicating the one right of which they are conscious ». The whole point of the encyclical on the «Restoration of Social Order » was to make the Christian world very acutely conscious of the virtue of contributive justice. In principle, the obligations binding employers and employees in commutative justice are perfectly clear in application, but they are not adequate. The solution of the problems of our social economy does not lie in stretching the fabric of commutative justice to cover things that it cannot logically cover. The solution lies in the promotion of understanding of the nature and application of the virtue of contributive justice... (210-212)

\&Contributive justice places a positive responsibility on every member of a society to contribute positively to the common good of that society. In the matter of wages, contributive justice demands not that the worker receive the economic value of his work, that is, exchange justice, but that he must receive the social value of his work. The full activity of the head of a family is a contribution to the wealth of the community by one of its members of all that he is capable of contributing. All the income of the community is made up of such contributions. In return for such effort, he has merited to receive from the community the means of living an adequate life as a human being... (232) ${ }^{7}$

(7) The Functional Economy, by Bernard William Dempsey, Prentice-Hall, Inc., Englewood Cliffs, N.J., 1958. 
Il y a aussi cette difficulté insoluble: définir ce que l'on entend par afamille moyenne ou «famille type » ou «famille normale s et encore déterminer les besoins de ce genre de familles.

Selon Messner, la «famille normale » n'est pas la «famille moyenne » ni la «famille type »; c'est celle dont la dimension permet réellement de remplir sa fonction comme cellule de la société et ceci ne peut pas être moins de trois et peut-être quatre enfants. ${ }^{8}$ Quant à la « famille moyenne», c'est un concept purement statistique qui se contente simplement de donner une idée d'un fait.

Une réserve s'impose au sujet de ce que l'on appelle « famille normale . Pour notre part, nous avons toujours compris qu'une famille normale, c'est celle où les parents ont accompli leurs devoirs de chrétiens et par conséquent le nombre d'enfants n'a rien à y voir. Une famille peut être aussi bien normale sans enfant qu'avec dix ou quinze.

Mais, concrètement, quelle famille est normale ou moyenne? La même famille peut seulement à un moment donné être dite normale ou moyenne. Et il y aura toujours, dans quelque circonstance que l'on puisse imaginer, seulement un très petit nombre de familles à qui vraiment et réellement s'appliquera ce concept. D'ailleurs, est-ce que le nombre d'enfants est un critère de besoins? Il est clair que deux familles possédant le même nombre d'enfants, mais à des âges différents (famille A: enfants de 1-3-5 ans; famille B: enfants de 12-14-16 ans) n'auront pas du tout des charges familiales identiques. Et un problème analogue se pose au sein de la même famille au cours de son existence.

Pourtant la raison d'être de la thèse du salaire familial c'est de permettre aux familles de subvenir à leurs besoins concrets, réels. Voilà pourquoi, avec Mgr Charrière, on ne peut pas s'empêcher de constater *combien est artificielle cette idée de famille moyenne s." Si l'on veut être logique dans ce genre de raisonnement, on ne peut pas ne pas aboutir à la nécessité pour l'employeur de payer le salaire familial relatif et écarter le salaire familial absolu.

D'autre part, la doctrine classique repose sur une hypothèse optimiste de l'économie. On se dit que dans l'état actuel ce n'est pas

(8) Social Ethics, Herder, St. Louis, 1949, pp. 308-309.

(8) La rétribution familiale des travailleurs, p. 12. 
possible, mais que cela viendra. Or, il faut constater qu'à l'heure actuelle, même dans les pays les plus développés économiquement et les plus prospères, comme les Etats-Unis et le Canada, en dehors de quelques industries privilégiées, le salaire familial absolu n'est pas payé. A fortiori le salaire familial relatif. D'ailleurs, le revenu national ne permettrait pas que soit versé à tous, (car le principe «d travail égal, salaire égal » vaut toujours), un salaire minimum suffisant pour subvenir aux charges d'une famille moyenne.

Il y a davantage, aucune économie ne pourrait y satisfaire non plus. ${ }^{10}$ Car le salaire familial absolu versé par l'employeur donne naissance à un cercle vicieux qui ne permettra jamais à la famille de faire face à ses besoins. Voici pourquoi. Ce salaire familial comme minimum va améliorer le standard de vie de tous les célibataires et de toutes les familles dont les charges sont en bas de la moyenne sans pour cela résoudre le problème du revenu de celles dont les charges sont au-dessus. Or l'on sait qu'en accroissant le pouvoir d'achat d'une catégorie de salariés déjà mieux partagée, on contribue à causer une inflation permanente et à créer de nouveaux besoins. En effet, les besoins dans la société ne sont pas seulement biologiques, mais sociologiques et psychologiques. "Le sentiment de bien-être et de richesse n'est pas absolu, mais se réfère toujours au niveau de bien-être et de richesse d'autres personnes, notamment des personnes se trouvant dans le même état social».

\section{Voici comment s'exprime là-dessus Beltrâo:}

- Si l'on accorde le même pouvoir d'achat à toutes les familles se trouvant dans le même état social mais n'ayant pas, en fait, les mêmes besoins essentiels, on alimente des besoins moins essentiels au détriment des besoins essentiels et ceci engendre une course salaireprix, puisque nul taux de salaires ne sera jamais suffisant pour suivre l'évolution trop rapide des « besoins ».

e Pour le salarié qui est, en fait, père de famille «nombreuse rappelons-nous combien ce concept est relatif -, il n'y a pas de problème d'《orientation de la consommation »: tout revenu supplémentaire va directement aux dépenses familiales courantes, comme les biens alimentaires, le loyer, les vêtements, etc.; tandis que le salarié n'ayant pas de charges familiales, toutes choses égales d'ailleurs, se crée faci-

(10) Pour voir la distribution des familles au Canada, c.f. Annexe I. 
lement des besoins en quelque sorte artificiels; ceux-ci vu la proportion considérable des ménages sans enfants à charge ou avec un enfant unique, deviennent rapidement «sociologiques », suscitent un « besoin social » nouveau que, dans l'hypothèse de pareille politique, le salaire direct devrait couvrir.

\& L'élévation des niveaux de vie est souhaitable et nécessaire; elle est fatale, d'ailleurs; mais, tout comme la «promotion ouvrière », il faut qu'elle soit collective, sans favoriser certaines familles, fussentelles la majorité, dans la mesure exacte où elles n'ont pas de charges familiales. Le contraire nous l'appellerions volontiers l'injustice familiale et toute injustice se venge, à la longue échéance; cette vengeance dans notre cas c'est bien la «grève des parents», menaçant toute la structure économique et sociale d'un pays, parce qu'ils ont été longtemps frappés par un système de distribution défectueux $\gg .{ }^{11}$

Contre la doctrine classique du salaire familial payé par l'employeur en justice commutative, Mgr Charrière apporte un argument de sens commun.

\& Veut-on prétendre qu'en raison du travail effectué chez son patron, à l'usine, au bureau ou aux champs, ce père de famille de quinze enfants a droit à un salaire qui permet d'élever aisément ses quinze enfants? Le père de famille de quinze enfants travaille, supposons-nous, à côté d'un célibataire ou d'un ouvrier qui n'a que deux ou trois enfants. Si on lui dit que la rétribution de beaucoup plus abondante qu'il reçoit lui est due en fonction des tâches professionnelles qu'il remplit chez son patron, comment voulez-vous qu'il puisse croire vraiment à un geste qui procède de l'égalité de traitement? Car justice suppose égalité: Justitia aequalitatem importat, comme le rappelle saint Thomas après Aristote. Il n'y a pas de justice là où manque l'égalité. Si donc la source, l'origine du droit aux allocations procèdent uniquement de la tâche accomplie chez le patron, le père de famille de quinze enfants sera le premier à se rendre compte que si on le rétribue davantage, c'est sans doute à cause de ses enfants, mais il ne verra pas en quoi il est ici question de justice. Pour lui, ce sera encore une forme d'assistance qu'il acceptera, sans doute, mais dont il ne verra pas le bien-fondé sur le plan de la justice et qui lui sera, malgré tout, à charge. Le patron lui-même fera un raisonnement tout semblable $\gg . . .12$

(11) PEDro C. BeLtrâo, Vers une politique de bien-être familial, Université grégorienne, Rome 1957, p. 273.

(12) La rétribution familiale des travailleurs, pp. 10-11. 
Et aussi qui ne raisonnerait pas de la même façon? A la suite de ces remarques sur le salaire familial relatif, Mgr Charrière ajoute:

«Certains ont vu cette difficulté et, pour la résoudre, ont imaginé l'idée d'un salaire pour familles « ordinaires ou normales ». Ils disaient que le patron est tenu à verser un salaire en justice mais pour une famille moyenne. Si le nombre d'enfants dépasse cette moyenne, il faudrait alors, disaient ces auteurs, recourir à l'assistance, à la bienfaisance, à la charité. Mais qui ne voit combien est artificielle cette idée de famille «moyenne »? Dans une région donnée, il s'agira de trois enfants, parfois de deux seulement, parfois de quatre ou cinq. Comment voudra-t-on faire comprendre au père de famille, qui aura deux ou trois enfants de plus que le nombre dit moyen ou "normal», que la justice n'est en cause que pour les deux premiers et pas pour les suivantsl $\$$ is

Il faut donc tenir compte de ces faits, de ces réalités, si l'on ne veut pas ergotter dans les nuages. C'est ce qui faisait dire à Father Edward Duff, dans un article où il présentait une vue panoramique des discussions actuelles sur le salaire familial:

《The facts are supplied by the application of the science of economics, but their significance should not be considered irrevelant by the ethician. For the moralist would remind the ethician, Nemo tenetur ad impossibile, and the man in the street would question the wisdom of announcing grave obligations - existing, at best, in the speculative order $\gg .{ }^{14}$

Pour terminer cette critique de la doctrine classique du salaire familial entièrement payé par l'employeur (en justice commutative ou sociale, comme l'on voudra), nous croyons qu'il est important de signaler qu'elle ne pourra jamais régler complètement le problème fondamental d'assurer à toute famille un revenu suffisant pour faire face à ses obligations. En effet, elle laisse de côté tous les travailleurs mariés qui ne sont pas des salariés. Et eux aussi, ont droit à un revenu familial. Il faudra donc trouver un système qui puisse tenir compte des droits de tous. Comment y arriver? Voyons les théories nouvelles.

(13) La rétribution familiale des travailleurs, p. 12.

(14) The Living Wage: a further note, in « Social Order \$, February 1957, pp. $82-83$. 


\section{3-Doctrines NOUVELLes}

a) Les Evêques dAustralie

Le 5 septembre 1954, l'Episcopat d'Australie faisait une déclarathon collective qui a eu un grand retentissement. Les évêques de ce pays prenaient une position bien précise sur le sujet que nous étudions.

- Dans le présent exposé, disaient-ils, il sera nettement établi que nous ne croyons pas que le régime du salariat tel qu'il existe aujourd'hui soit le mode de rémunération le meilleur ou même le plus efficace. Nous proposerons, pour le remplacer, un système de revenu familial... Au-dessus de la notion de salaire, il faudrait placer la conception d'un * revenu familial» suffisant, dont le salaire ne constitue qu'une partie ${ }^{15}$

Ils distinguent donc entre salaire et revenu; ils ébauchent une théorie selon laquelle le juste salaire serait simplement le salaire vital individuel, et l'Etat devrait fournir des allocations spéciales aux travailleurs mariés pour pourvoir aux charges supplémentaires que leur imposent leurs responsabilités.

« Nous proposons, disaient-ils, que ce fardeau repose sur la communauté ou l'Etat. En justice sociale, en tant que distincte de la justice stricte, l'Etat doit venir à l'aide du chef de famille. Ne devrait-on pas demander à l'Etat qu'il fournisse un subside gratuit à la famille. Car, outre le devoir de charité chrétienne, l'homme qui se marie et élève une famille rend un service important et vital à la stabilité, au progrès et à la défense de l'Etat, et l'Etat doit volontairement acquitter sa dette. En effet, en Australie, l'Etat reconnaît cette obligation quand il accorde des allocations pour les enfants et d'autres bénéfices sociaux. En conséquence, le travailleur qui a des responsabilités familiales, en outre du salaire qu'il a droit, comme le célibataire, d'obtenir de son employeur, recevra des fonds publics, sous forme de bénéfices sociaux, une allocation pour sa femme et chacun des enfants qui sont à sa charge.

* Si notre société était organisée en fonction des secteurs professionnels, les travailleurs et les employeurs étant groupés ensemble dans des conseils industriels, l'argent nécessaire au paiement de ces allocations pourrait provenir d'abord de l'industrie concernée qui établirait une caisse de compensation à même laquelle les

(15) L'évolution du système du salariat..., traduction française dans \& Bulletin des dirigeants de la CTCC s, vol. II, no 2, mai 1955, pp. 2-9. 
allocations pourraient être tirées. Dans l'état actuel de l'organisation industrielle, en Australie, il semble qu'il n'y ait d'autre moyen que de faire assumer le paiement de ces allocations par l'Etat ».

Les évêques d'Australie, après avoir proposé un aménagement concret de leurs principes (Annexe II), ils prenaient la précaution de dire que leur doctrine n'allait pas à l'encontre de l'enseignement social de l'Eglise.

«Dans la grande encyclique QUADRAGESIMO ANNO, Pie XI déclarait qu'il est impossible d'établir un juste revenu pour le travail d'un homme uniquement en prenant en considération un aspect de la question. Plusieurs facteurs entrent en cause et, parmi eux, le problème des «besoins *, l'état des affaires individuelles et la situation de l'économie nationale. Le concept de revenu familial, élaboré ci-dessus, tient compte de tous ces problèmes. De plus, il ouvre la voie d'accès vers «le salaire social» énoncé par Pie XII. Nous ne doutons pas qu'il faudra du courage et de la prévoyance de la part de tous les intéressés pour instituer un pareil régime. Sur une longue période, cependant, les sacrifices entraînés par l'établissement d'un nouveau régime seront presque sûrement moins douloureux que les tensions constantes et périodiques occasionnées par les anomalies et les injustices de l'ancien système 》.

On n'a pas à être surpris si une telle thèse a fait sursauter certains moralistes et même s'il s'en est rencontré pour accuser les évêques australiens de verser dans le socialisme. En réponse à un jésuite anglais, qui, pour condamner ces évêques, avait sorti tout son arsenal de moralistes soutenant la doctrine classique, le professeur Fogarty écrivait:

«A Lehmkul in Father Crane's library is not worth two bishops in the bush ». The Australian statement represents \& a revolution in thinking about the living wage which took hold some time ago in France, increasingly also in other continental countries and is now penetrating into the heartland of the Jesuit social school itself $» .{ }^{16}$

\section{b) Mgr François Charrière}

L'évêque de Fribourg, Mgr François Charrière, dans sa lettre pastorale du carême 1956, établit une thèse analogue et arrive aux mê-

(16) Cité par Edward Duff, s.j. The Living Wage, dans \& Social Order > September 1955 , p. 297. Dans une note, le Père Duff ajoute que les jésuites allemands penchent de ce côté. 
mes conclusions. Cependant on rencontre chez lui quelques variantes avec les évêques australiens.

Il parle de rétribution familiale du travailleur. Cette rétribution est composée, pour les pères de famille, du salaire vital individuel payé par l'employeur en vertu de la justice commutative et aussi des allocations spéciales pour satisfaire aux besoins de sa famille, payées par l'Etat, en vertu de la justice commutative. Il base son argumentation, lui aussi, sur plusieurs textes pontificaux et spécialement sur celui de Pie XII en 1949:

"Il convient de rappeler que des égards plus attentifs sont dus aux familles chargées d'enfants; dégrèvement d'impôts, subsides, allocations, considérés - dit le Pape, et ceci est très important non pas comme un don purement gratuit, mais plutôt comme une indemnité très modeste due au service social de première valeur que rend la famille, surtout la famille nombreuse ». (A.A.S., 1949, p. 554 .) ${ }^{17}$

Et immédiatement, il continue:

\& Ce texte capital nous fournit la clef d'un problème souvent mal résolu. Le Pape, en effet, après avoir rappelé qu'il ne s'agit pas d'un don, mais d'une «indemnité », donc d'une question de justice stricte, fait appel pour la justifier, au "service social de première valeur » que rend la famille. Le Pape ne pense donc pas seulement à l'employeur qui jouit du travail de l'ouvrier, mais considère, comme étant également bénéficiaire de la famille, la société toute entière, tenue, dit le Pape, à «indemniser» le père de famille pour ses «services sociaux». C'est là une pensée génératrice de clarté, car, si l'on veut ne considérer comme débiteur du chef de famille que l'employeur chez qui celui-ci travaille, au bureau, à l'atelier, aux champs, on aboutit à une véritable impasse .

Après avoir exposé toute sa conception, et démoli la doctrine classique, il conclut sa thèse de la façon suivante:

«Nous croyons avoir ainsi montré comment la rétribution familiale du travailleur, quel qu'il soit, est vraiment due en stricte justice et, nous disons le mot, en justice des échanges, en justice commutative, au point d'obliger à restitution si elle n'est pas satisfaite. La justice commutative, celle des échanges, comme le mot l'indique, suppose qu'une rétribution est donnée à la place

(17) Opus cit., p. 9. 
d'un service ou d'une valeur possédée à titre de propriété et à propos de laquelle il y a échéance. Quel que soit le nombre de ses enfants, le travailleur aura conscience qu'il ne s'agit pas, dans la rétribution qu'il reçoit proportionnellement au nombre de ses enfants d'une question d'assistance, mais bien d'un échange pour les services qu'il rend à la profession et à la société tout entière en élevant dignement les enfants que la Providence lui a confiés. c Telles sont les conclusions doctrinales qui découlent de l'affirmation très nette des Encycliques pontificales et aussi du sens commun. Comme on le voit, il s'agit là d'une croissance homogène de la doctrine de l'Eglise. Il est temps que les chrétiens s'en inspirent d'une manière efficace ${ }^{18}$

A une objection qu'on lui a faite, à savoir que les documents pontificaux déclarent à maintes reprises que le salaire familial est exigé par la justice sociale, l'évêque de Fribourg répond qu'il ne voit pas comment l'Etat ne peut pas, en plus d'obligations en justice sociale, ne pas avoir d'obligations en justice commutative. La justice sociale oblige tous à promouvoir les institutions et les lois qui donneront à chacun ce qui lui est dû. Ainsi le salaire familial est exigé à la fois par la justice sociale et la justice commutative. Il ajoute à son correspondant une remarque qui ne manque pas de piquant.

\&We cannot be content with declaring that the family living wage is due in justice whether general or social. We must determine who, in the concrete, is obliged to provide that income and because of what ethical principles. Otherwise we are giving the father of the family a check on some unknown person. And the father cannot know where to cash it ${ }^{19}$

Pour notre part, nous ne sommes pas prêt à souscrire à l'obligation pour l'Etat de verser en justice commutative des prestations familiales sans ajouter quelques distinctions. Il est vrai que l'Etat peut avoir des obligations en justice commutative. Mais il faut que celles-ci soient déterminées par des mesures de droit positif, comme la constitution ou la législation. C'est seulement après que cette détermination aura été faite qu'il sera obligé à la restitution. Cependant, c'est en vertu de la justice sociale qu'il peut être amené à les effectuer.

Il y a un autre point sur lequel il semble y avoir une divergence entre l'évêque de Fribourg et les évêques australiens. Ceux-ci ont soutenu que théoriquement il serait préférable que les subsisdes aux

(18) Opus cit., pp. 15-16.

(19) Social Order, January 1958, p. 45. 
familles, au lieu de provenir des fonds de l'Etat, viennent de caisses établies sur le plan professionnel, mais que cela était impossible d̀ réaliser en Australie. Ils tenaient au principe, cependant. En Suisse, la situation est différente. Ces caisses industrielles existent déjà. Lexpérience a démontré, selon l'évêque de Fribourg, que ce genre d'organisation est insatisfaisant, même qu'il est impossible, sans le secours de l'Etat, de faire disparaître les inégalités interprofessionnelles et qu'enfin c'est tout le monde qui bénéficie des familles nombreuses. Pour que l'Etat puisse accomplir ses obligations en justice commutative envers elles, il ajoutait:

\& This could be achieved without creating complicated organization and without smothering the family in useless groupings. The family must maintain its primacy and its liberty. Freedom in misery, however, is not freedom 》. ${ }^{20}$

\section{c) Michael P. Fogarty}

Le professeur Fogarty, lui aussi, rejette fermement la doctrine classique du salaire familial et il en propose une autre qui ne manque pas d'originalité. Il s'oppose à tout système d'allocations familiales ou de subsides venant de l'Etat et soutient que chaque famille doit subvenir à ses besoins concrets à partir directement du salaire que reçoit son chef.

C'est la justice commutative qui règle la détermination du salaire, car « à travail égal, on doit payer un salaire égal». Mais la valeur du travail est celle qui répond aux besoins d'une famille < normale ». Pour Fogarty, le mot «normal » n'a pas la même signification que chez les tenants de la doctrine classique. On sait, en effet, que les besoins concrets auxquels doit faire face le chef de famille varient non seulement d'une famille à une autre, mais aussi dans la même famille au cours de son existence.

Dans une société bien organisée, dit-il, la valeur de tout le travail salarié doit être suffisante pour supporter tous les salariés avec leurs dépendants. Il s'ensuit que la somme des listes de paye, en justice commutative, doit au moins être l'équivalent de toutes ces charges. Mais si la valeur créée par l'ensemble des salariés, grâce à leur travail, doit à un moment donné équivaloir à leurs besoins, il est probable - et en fait c'est ce qui arrive - que ce ne soit pas vrai pour chaque travailleur individuel.

(20) Social Order, January 1958, p. 45. 
Par contre, l'individu va produire assez durant toute sa vie pour couvrir les besoins de toute sa vie, bien qu'il soit très peu probable que ses gains quotidiens coïncident avec ses besoins quotidiens. Avec le développement de l'actuariat, il est possible de prévoir assez exactement ce qui va se passer pour l'ensemble des salariés. Par conséquent, si un homme doit gagner assez pour vivre avec sa famille, son salaire doit lui permettre de payer des primes nécessaires à l'assurer contre toutes les contingences de la vie, donc les besoins familiaux.

Chaque travailleur recevra le même salaire que son compagnon accomplissant le même travail. Ce salaire doit être suffisant pour faire vivre convenablement le travailleur individuel et pour payer des primes contre les risques familiaux qui seront versées dans un fonds commun organisé au sein de chaque industrie. C'est ce fonds commun qui, à son tour, indemnisera les travailleurs selon les besoins concrets des personnes dont ils ont la charge. De cette façon, tout sera réglé sous l'empire de la justice commutative. L'employeur, payant exactement la valeur-travail, remplit son contrat en vertu de la justice commutative. Et il en est de même pour le contrat d'assurance. ${ }^{21}$

Cette théorie du professeur Fogarty ne manque certainement pas d'ingéniosité. Pour notre part, si intéressante qu'elle soit, nous lui voyons quelques difficultés de réalisations. En effet, elle ne tient pas compte du nombre considérable de travailleurs qui ne sont pas salariés et qui ont droit aussi au revenu familial. De plus, elle suppose une main-d'oeuvre salariée complètement immobile. Or l'on sait que des salariés changent d'emploi, soit en devenant des travailleurs autonomes, soit en allant travailler pour d'autres employeurs, tant dans la même industrie que dans d'autres industries. Cette assurance contre les risques familiaux pourrait difficilement, pour remplir efficacement son but, être réalisée au moyen d'une caisse d'entreprise ou d'industrie. Il faudrait une caisse nationale. Une telle caisse pourrait-elle alors garder un caractère privé? Comment organiser la perception des primes sans la loi? Ainsi n'aboutirions-nous pas, en somme, au même système que Mgr Charrière ou les évêques d'Australie, par une autre voie. En tous cas, il est une chose qui nous semble certaine: c'est l'impossibilité de revenir en arrière et de faire disparaître, dans un pays

(21) Michael P. Fogarty, Family Allonances, Catholic Social Guild, Oxford, 1956. Family Living Wage, dans \& Social Order 》, December 1955, pp. 481462; Wage and Normal Family, dans e Social Order \$, April 1958, pp. 191-192; voir aussi: E. Duff, The Living Wage, dans \& Social Order \$, September 1955, pp. 294, sq; J.R. Kirwan, Novelties in Wage Theory, dans \& Social Onder 》, December 1957, pp. 440-445. 
comme le nôtre, des mesures étatiques de sécurité sociale comme les allocations familiales, les pensions de vieillesse, l'assurance-maladie, etc.

On aura pris la peine de noter que toutes ces théories qui se développent en marge de la doctrine classique ont ceci de commun qu'elles ne prétendent pas s'écarter des principes de la doctrine sociale de l'Eglise, mais plutôt elles se présentent comme son développement, son complément. Elles ne comportent pas de contradictions internes qui les empêchent d'être économiquement réalisables et les travailleurs qui sont chargés de famille peuvent réellement obtenir ce dont ils ont concrètement besoin. Ce n'est plus seulement un droit illusoire, un chèque sans signature, comme le disait avec humour Mgr Charrière. Elles s'entendent pour rejetter l'obligation qu'il y aurait pour un employeur déterminé à payer directement à un travailleur déterminé un salaire strictement familial en justice commutative. Pour les évêques australiens et pour l'évêque de Fribourg, l'employeur n'est tenu en justice commutative qu’à payer le salaire vital individuel. Alors que chez le professeur Fogarty, c'est le salaire vital individuel plus le montant nécessaire à couvrir les primes d'assurances contre les risques familiaux.

\section{4 - Constó́rations finales}

La notion de salaire a beaucoup évolué même si chez plusieurs moralistes de la tradition classique elle reste encore assez équivoque. En ces dernières décades, cependant, on est arrivé à découvrir et a dissocier deux réalités qui ne se recouvrent plus complètement dans le salaire.

\section{Le salaire est à la fois un cotit et un revenu.}

Le salaire-coût, c'est la rémunération du travail envisagée du côté de l'employeur. Il rentre dans son coût de production comme les autres dépenses. Il comprend tout ce que le travail entraîne de déboursés pour mettre sur le marché un produit ou fournir un service: montant dans l'enveloppe de paie, cotisations diverses à des caisses, soit déterminées par la loi ou par des conventions.

Le salaire-revenu, c'est la rémunération du travail envisagée par le salarié. Il se compose de ce qu'il trouve dans son enveloppe de 
paie, avec en plus, les bénéfices sociaux dont il jouira et dont les cotisations ont été payées par son employeur.

Le salaire-revenu n'est pas nécessairement identique au salairecout. Ainsi, lorsque dans une convention collective il y a un plan d'assurance-maladie dont les primes sont payées uniquement par l'employeur, le travailleur qui a été malade et a reçu des prestations se trouve à recevoir un salaire-revenu plus grand qu'un autre de ses compagnons qui, travaillant au même taux n'a pas été malade. Déjà sur le plan de l'entreprise, ce salaire-revenu n'est pas lié à la contribution personnelle à la production.

Du fait que du point de vue économique, au niveau de l'entreprise, on puisse envisager seulement la productivité du travailleur et, tout au plus la productivité générale de l'entreprise (et dans ce cas, encore on ferait bénéficier un travailleur au dépend d'un autre), cela ne signifie pas que l'on doive fatalement se résoudre à ne pas tenir compte de la valeur morale du travail, laquelle est aussi essentielle et fonde le travailleur à disposer d'un revenu lui permettant de pourvoir à ses besoins réels ou éventuels, individuels ou familiaux. Au contraire, dans une société bien ondonnée sur des bases de justice sociale, ces besoins doivent être couverts. Car le travail, comme ne cesse de le rappeler la doctrine sociale de l'Eglise, comporte non seulement un aspect personnel, mais aussi un aspect nécessaire et universel. ${ }^{22}$

La valeur du travail n'est pas épuisée par le bénéfice économique immédiat qu'en reçoit l'entreprise. Pour être évalué pleinement, le travail doit être envisagé dans sa contribution à l'ensemble de l'économie. Il faut, alors, pour le rémunérer selon cette pleine valeur, opérer une re-distribution à un niveau supérieur, que ce soit celui de l'industrie ou de l'économie nationale. C'est ce que Pie XII laissait entrevoir dans son allocution aux agriculteurs italiens en 1946:

«Continuez à considérer votre travail suivant sa valeur profonde, comme votre contribution personnelle et celles de vos familles à l'économie publique. Grâce à lui, s'établit votre droit légitime à un revenu suffisant pour assurer le maintien de votre dignité d'hommes et aussi pour satisfaire à vos besoins culturels $\gg .{ }^{23}$

(22) Mgr Montini, Lettre d la semaine sociale du Canada, 1949, UTZ 365.

(23) UTZ 2514. 
Calvez et Perrin, citant ce texte dans leur ouvrage \& Eglise et société économique, ajoutent:

- C'est pourquoi la rémunération du travail prend place dans le cadre de la répartition sociale des revenus. Cette dernière s'effectue à des niveaux divers. Elle s'amorce dans les unités de production inférieures, mais elle exige d'être corrigée, aménagée par des transferts au niveau de l'économie nationale ou globale, dans laquelle tout travailleur apparaît comme le porteur d'un droit à un revenu ». ${ }^{24}$

Dans son volume Vers une politique de bien-être familial, Beltrâo a développé cette thèse d'une façon très claire et très logique. Il concluait de la façon suivante:

\& En voulant serrer de plus près la conciliation entre les deux points de vue (économique et moral), on pourrait soutenir que, si l'on parvient à déterminer par des critères économiques l'apport du travailleur, à la production, le moraliste endosse le salaire-coût correspondant comme étant dû en vertu de la justice commutative: celle-ci exige une équivalence des apports de part et d'autre, c'est un do ut des; elle ne peut donc s'étendre à rien qui dépasse en valeur l'apport réel du travailleur; tout revenu supplémentaire ne serait dû qu'en vertu de la justice sociale.

-Il apparaît ainsi que la célèbre controverse des catholiques sociaux sur la question de savoir si le \&salaire familial » était dû en vertu de la justice commutative ou en vertu de la justice sociale, se fondait sur un «faux problème »: le simple fait de poser le problème du «salaire familial » indiquait qu'on se référait aux besoins du travailleur; or, dans l'équivalence des rapports, exigée par la justice commutative, d'après la définition qu'en donnent les moralistes eux-mêmes, les besoins n'entrent pour rien ».

- Il apparaît, d'autre part, que la Sécurité sociale, et en particulier la politique familiale, sont, aux yeux du moraliste, un des moyens pour réaliser la justice sociale; et aux yeux de l'économiste, le moyen le plus économique de le faire $\${ }^{25}$

En tenant compte des principes de la morale et des données économiques, il nous semble tout à fait sûr que le droit sur les biens de la nature n'est pas immédiatement fondé sur le travail, mais sur leur essentielle destination à servir les hommes. Il l'est cependant médiatement parce que le travail est un devoir et le moyen normal

(24) Calvez et Pernin, Eglises et société économique, p. 312.

(25) Pedro Calderan Beltrâo, Vers une politique de bien-être familial, 1957, p. 280. 
de se procurer ce dont on a besoin. Ceci, c'est du droit naturel secondaire, tout comme la propriété privée. Le travail n'est pas le moyen exclusif d'acquérir des biens, quoique, dans une société normale, le revenu familial soit constitué principalement et fondamentalement par la rétribution du travail du chef de famille.

Le danger est réel chez le père de famille de s'en remettre à d'autres pour absorber des charges qu'il devrait assumer lui-même quand il le peut. Et il n'y a pas de doute aussi que les bénéficiaires d'un revenu familial amélioré qui ne vient pas immédatement du travail du père soient portés - au moins temporairement - à éprouver un sentiment d'indépendance accrue envers leurs parents.

Mais ce ne sont pas là des motifs suffisants pour priver les membres de la famille de droits qui leur viennent de la nature. Il faut avoir limagination et le courage de trouver et de mettre en application des moyens compensatoires.

Le premier, c'est de développer chez tous une compréhension plus grande de la conception chrétienne de la famille et des rapports. qui doivent s'établir entre ses membres. Les liens biologiques et spirituels qui existent entre les parents et leurs enfants devraient être aussi forts que ceux qui proviennent d'une dépendance économique. Une société où l'autorité parentale reposerait surtout sur la dépendance économique des enfants envers leurs parents serait déjà très malade.

Le second, c'est de susciter des institutions où les chefs de famille pourront faire valoir leur point de vue et être amenés à participer à la gestion de tous les organismes administratifs se rapportant à la famille, qu'ils soient d'ordre privé ou public. Si l'on veut vraiment éviter de verser dans l'étatisme, il est indispensable d'accroître le caractère démocratique des institutions économiques et sociales en assurant une représentation des intéressés.

Dans la remarquable allocution de Pie XII, qui a été utilisée par les évêques australiens et l'évêque de Fribourg comme inspiration de leurs thèses sur le revenu familial, le pape insiste sur ces points:

«Le programme de cette action tendant à consolider la famille, à élever son potentiel, à l'intégrer dans le mécanisme vivant du monde peut se ramener à quelques chefs précis: suppléer à l'insuffisance de la famille en lui procurant ce qui lui manque pour exercer sa fonction domestique et sociale... unir entre elles les 
familles en un front solide, conscient de sa force... permettre à la famille de faire entendre sa voix dans les affaires de chaque pays, comme de toute la société, de telle sorte qu'elle n'ait jamais à souffrir de leur part, mais au contraire à en bénéficier le plus possible.

- Comme les chemins que suivent l'économie et la politique ellemême seraient différents si ce principe fondamental devenait le guide commun de tous les hommes consacrés à la vie publique $\mathbf{8}^{26}$

Avant de terminer, nous croyons qu'il n'est pas du tout inopportun de faire une mise-en-garde à ceux qui nous auront suivi dans cet exposé et qui seront peut-être tentés de l'exploiter pour satisfaire leurs visées égoistes ou justifier leur inaction.

I y a une obligation pour chacun d'apporter son concours à accroitre la productivité et la production si l'on veut que les familles puissent obtenir le revenu familial auquel elles ont droit. Car il est impossible de distribuer en salaire et de re-distribuer en prestations familiales plus que ne peut le permettre le revenu national dont une part doit être aussi réservée à la rémunération du capital, aux dépréciations, aux nouveaux investissements et aux dépenses de l'administration publique.

$\mathrm{Si}$, comme nous le croyons, le salaire familial n'est pas dû en justice commutative par l'employeur et que celui-ci peut s'en tenir à une rémunération en rapport avec le rendement économique du travailleur, cela ne signifie aucunement que tout acroissement de salaire doit nécessairement être bloqué, ni que cet employeur a rempli toutes ses obligations quand il l'a payée. Bien au contraire. N'est pas excusable de verser lui-même une rétribution qui tienne compte des besoins familaux, celui qui de toutes ses forces, avec tous les moyens dont il dispose tant dans le domaine économique, professionnel que politique, ne contribue pas à mettre sur pied des institutions pour que chaque famille soit assurée d'un revenu familial lui permettant de satisfaire à ses besoins.

(26) Pie XII, allocution aux délégués de l'Union internationale des organisations familiales, 20 septembre 1949, UTZ no 2813. 


\section{Annexe I}

\section{Unitís familiales au Canada}

D'après le rencensement du Canada, en 1956, la taille moyenne des familles était dans l'ensemble du pays 3.8 personnes et dans la province de Québec 4.2 personnes. Or, si l'on versait un salaire famihial sur le nombre moyen de personnes, on se trouverait à sustenter $3,167,100$ personnes imaginaires. Et, par contre, on ne s'occuperait pas des 2,149,743 personnes qui ont le malheur de faire dépasser dans leur famille le chiffre moyen au Canada. Et nous ne parlons pas des célibataires en emploi qui auraient aussi le salaire familial. Voici un tableau significatif.

FAMILLES SELON LE NOMBRE ET LA MOYENNE DE PERSONNES au Canada et dans le Qúfbec - 1956

Nombre de personnes

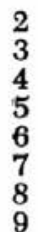

Total

Moyenne de personnes par famille
Québec Nombre de familles

248,461
201,250
181,091
122,336
78,261
50,027
32,549
56,439

970,414

4.2
Canada Nombre de familles

$$
\begin{array}{r}
1,125,302 \\
816,496 \\
759,064 \\
455,869 \\
245,445 \\
130,018 \\
73,590 \\
105,716
\end{array}
$$

$3,711,500$

3.8

Source: Population, familles selon la taille, Bulletin, 1-16-27-7 1957.

\section{Annexe II}

Aménagement proposé PAR les Evêques d'Austractr

Les composantes du revenu familial

En vue de l'application pratique de ces principes généraux, Nous proposons l'aménagement suivant:

a) Il devrait y avoir un salaire-standard qui serait celui du célibataire. Celui-ci comprendrait ses besoins essentiels en ma- 
tière de nourriture, de vêtements et de logement. Il comporterait une somme modeste pour les divertissements et lui permettrait d'économiser une partie de ce qui sera nécessaire à son mariage futur. Il lui permettrait aussi de commencer à faire une réserve normale, par le moyen des assurances publiques et privées, en prévision de la vieillesse et pour les périodes de maladie et de chômage. Il fournirait quelque occasion par quoi l'homme prudent, par la pratique de l'épargne, pourrait acquérir un modeste patrimoine en propre. La même somme serait établie pour l'un et l'autre sexe.

b) A son mariage, le travailleur aurait droit à une augmentation de revenu pour subvenir aux besoins de son épouse en plus des siens et aussi pour se faire quelque épargne en prévision des dépenses qu'entraînerait la naissance d'un enfant. Il aurait également droit à un boni qui lui permettrait de payer partiellement sa maison et ses meubles.

c) A la naissance de chaque enfant, il aurait droit à une allocation hebdomadaire supplémentaire pour absorber le coût de ses enfants dépendants. Les allocations pour les dépendants devraient demeurer aussi longtemps que la dépendance existe.

Si notre société était organisée en fonction des secteurs professionnels, les travailleurs et les employeurs étant groupés ensemble dans des conseils industriels, l'argent nécessaire au paiement de ces allocations pourrait provenir d'abord de l'industrie concernée qui établirait une caisse de compensation à même laquelle les allocations pourraient être tirées. Dans l'état actuel de l'organisation industrielle en Australie, il semble qu'il n'y ait d'autre moyen que de faire assumer le paiement de ces allocations par l'Etat.

\section{Les avantages dun système de revenu familial}

Les avantages d'un semblable système sont clairs et ont été décrits dans le « Programme pour la Paix».

1) Il satisfera aux exigences individuelles normales et raisonnables de chaque travailleur adulte, homme ou femme. Il donnera l'assurance que les employeurs satisferont aux obligations spécifques qui leur sont imposées en justice stricte pendant que 
la société dans son ensemble remplira les obligations de la justice sociale.

2) En assurant le même salaire minimum aux travailleurs, quel que soit leur sexe, il éliminera la concurrence entre les sexes. Le travail féminin ne sera pas exploité sous prétexte qu'il est meilleur marché. Pour le même motif, les hommes ne seront pas remplacés par les femmes dans l'industrie.

3) Il corrigera la situation dans laquelle un jeune homme de vingt-et-un ans, qui n'a ni dépendant ni responsabilité, autre que celle de pourvoir à sa propre subsistance en matière de nourriture, de vêtements et de logement (les deux derniers facteurs énumérés se trouvant souvent inclus dans une petite "pension payée aux parents») accède dès sa majorité en pratique au même revenu qu'à l'homme marié avec des enfants.

4) Le «Salaire-standard » étant basé sur les besoins d'une personne célibataire, homme ou femme, le salaire à 21 ans, bien que suffisant, pourrait être inférieur. Cependant, à cause des garanties décrites ci-dessous, il n'y aura aucun avantage pour les employeurs à remplacer les travailleurs âgés par des jeunes.

5) Les dispositions qui garantiront des allocations complètes pour les enfants auront au moins tendance à éliminer les raisons économiques invoquées en faveur de la restriction des naissances dans la famille ouvrière.

6) Une revision complète de la structure du revenu familial, incluant les gages, tiendrait compte naturellement de suppléments satisfaisants pour les travailleurs véritablement qualifiés. Il donnerait l'assurance que la situation comparative des travailleurs qualifiés et des manoeuvres ne serait pas détruite par l'usure du temps.

Bulletin des Dirigeants de la C.T.C.C., Vol. II, no 2, mai 1955, pp. 7-8. 